\title{
Good Girl
}

\author{
Amy E. Robillard
}

Amy E. Robillard is professor of English at Illinois State University, where she teaches courses in rhetorical theory, composition studies, and life writing. She is the author, most recently, of We Find Ourselves in Other People's Stories, and the co-editor, with Shane Combs, of How Stories Teach Us: Composition, Life Writing, and Blended Scholarship. She lives in Bloomington, IL, with her husband, Steve, and their three dogs.

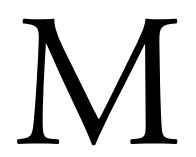

y first thought was inappropriate. My second thought, inappropriate. But they both rushed into my head so quickly they actually couldn't be classified as thoughts so much as involuntary reflexes.

"I see you out here with these dogs off leash every morning and you don't have control of them," she cried at me.

She was slowly gathering herself off the sidewalk, brushing her thighs. She stood, took her head in her hands, unsteady on her feet. Then the tears came.

"You-you're out here every morning." She looked down at her dog, also now unsteady on her feet. She rubbed her hands over her dog's body, walked her a little and cried out.

"She's hurt. l'm gonna need to get your information."

I stood there, eyes wide, horrified. Essay was now on her leash. I had just pulled her off the woman's dog, and the first thought that came to my mind when she accused me of having no control over Essay was that I was not out here every morning. The second thought was that I never let both dogs off leash. Only Essay.

In the face of trauma, I was setting the record straight, if only in my head.

There's a story I tell myself, one I try to maintain by walking the dogs regularly and posting frequent photos of them on social media, one I persuade myself is true by talking about their clever names and loving them desperately. That story is that I am a good dog owner. But I am not a good dog owner. I am impatient. Too impatient to ever train them properly. They are trained enough to sit for a treat, but neither dog knows any other commands. They don't know "stay" or "come" or even "down." They don't even really respond to all the nos I offer up in a day. They pretty much do what they want and I love them for it.

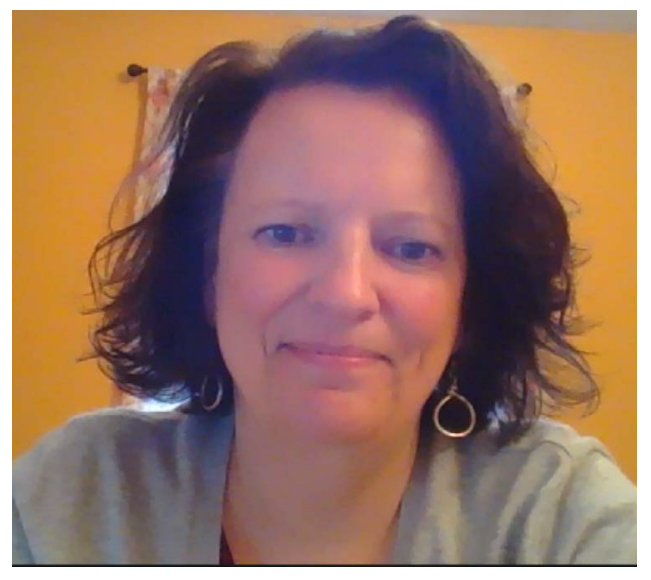

\section{Abstract}

In this personal essay, an act of aggression by my nine-year-old dog triggers me to contemplate the relationship among touch, communication, and violence during a pandemic. More specifically, after I let her run (illegally) off-leash at a park near my home, my dog, Essay, attacked another dog for what seemed like no reason. I was horrified, and, having grown up in an abusive home, had to come to terms with being on the other side of an attacker/victim dynamic while I waited to hear whether the other dog would be okay. This prompts me to consider what it means to control our dogs, whether words can touch us when we cannot touch one another, and what it means to be a good person during a pandemic.

\section{Keywords}

violence, touch, dogs, abuse, pandemic 


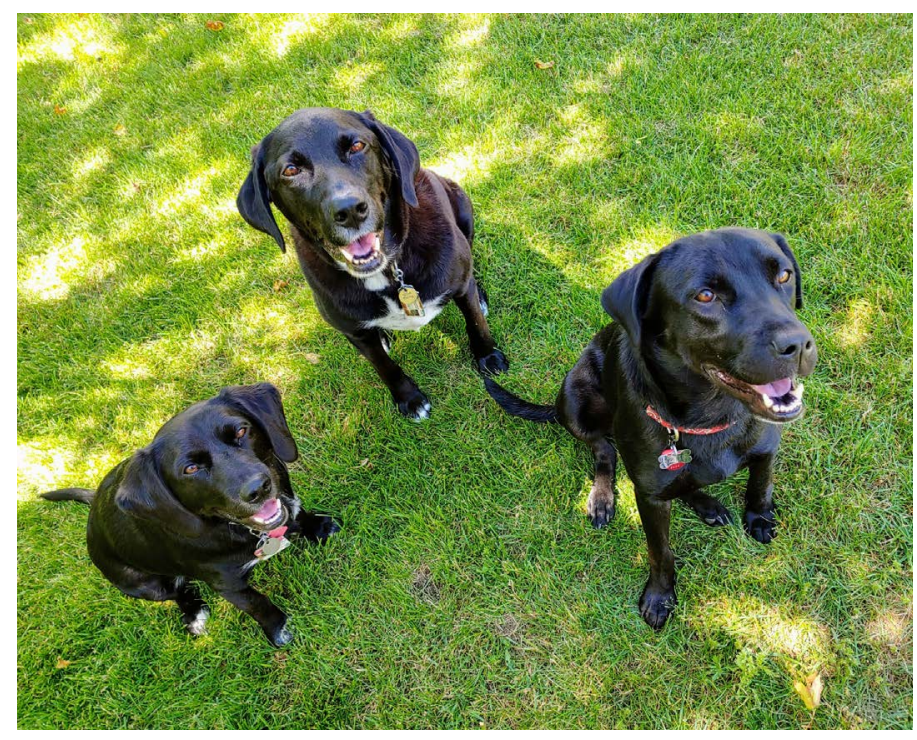

Marshall, Essay, and Hattie.

Essay attacked the other dog in early April, during the coronavirus pandemic. My husband Steve and I had been working from home for three weeks. He works for an insurance company, and I teach for a university. My classes had been moved online, and I was now communicating with students exclusively in writing. Our leaving the house had been reduced to going to the grocery store once every ten days or so and walking the dogs twice a day.

I had been just about to clip Essay's leash to her collar when she got away from me. l'd let her run off-leash in the neighborhood park, the one we walk to all the time. This is the park where we so often see Baxter, the huge black lab who is never anything but happy. He and Essay had run together while Marshall, our other dog, tried to play catch-up. I never let Marshall run off-leash; instead, I kept his leash attached to him and let him trot off behind Essay and Baxter. Marshall's legs are so short-he's part beaglethat I'm pretty confident I can catch him if he runs off. But I don't trust him enough to take the leash off him. He's only two. I trust Essay; she always comes when called. It may take me calling her a few times, but eventually she comes to me.

After our visit, Baxter and his mom, Janet, had gone their own way, and I was just about to hook Essay's leash to her collar to walk her home when Essay caught sight of the woman and her dog, whose name, I now know, is Casey. But Essay darted away from me, toward Casey. I could feel my hand run along her back as she did and for a split second, I thought about grabbing her by her tail to stop her.

You know how they always say, when describing any kind of trauma, that "it happened so fast"? And you wonder, really, did it happen so fast that you can't remember or you can't describe it, or are you just not able? But I'm here to tell you these things really do just happen so very fast. One second my hand is sliding down Essay's back, and the next, she is rolling on the ground with Casey, a fourteen-year-old dog, and her mom, a woman in her fifties. Casey's mom had fallen while trying to separate the dogs. There was screaming. I probably screamed. I always think about Jo Ann Beard, who writes about herself in one of her essays that her screaming button gets stuck on. They were probably thirty or forty feet from me, but I am no good at estimating distances. It didn't take me long to get to them, and I immediately grabbed Essay by the collar and pulled her off both of them while the image of the three of them on the ground seared itself into my memory.

\section{$* * *$}

We're living through a pandemic. Nothing is the way it used to be. Nothing is like what l'm coming to call The Time Before. We in Illinois, like so many others across the country, are on a stay-at-home order until at least the end of the month. This means we are not supposed to be going anywhere nonessential. We can go to the grocery store and to the pharmacy and to get gas, though my first thought on that last bit was, get gas to go where? We are all supposed to be practicing social distancing, which means we're supposed to stay at least six feet from one another, but what it really means is not hanging out with friends. No gatherings, no parties, no lunch dates. The only people we can touch are those we live with.

I have never been a hugger. It occurred to me that if I had lived through this pandemic as a child, if I had had to be on lockdown with my family when I was a kid, I would have had no touch other than abuse for months.

When we get married, we promise to love our spouse in sickness and in health, for richer or for poorer, until death do us part. What are the vows we make when we adopt a dog? Is it something like, in old age and in youth? Anybody can love a puppy; the harder part is loving a dog the way she needs to be loved when she feels anxious, when she is afraid of the thunder, when she can no longer see. The harder part is loving a dog when you don't understand what is wrong, why she is behaving the way she is, and she can't tell you either of these things because she can't tell you anything. She cannot speak.

Because we are living through a pandemic and nobody is allowed to touch anybody else-no hugging, no kissing hello, no shaking hands, no patting one another on the shoulder-one of the things that occurred to me when Essay jumped on Casey was how much touch was involved. This is something I never would have thought about in The Time Before and I don't think I would have gone over to the woman to put my hand on her shoulder in The Time Before, or would I have? In any case, I didn't go over to the woman, I didn't put less than six feet between us. I couldn't. I was in shock. I don't remember clicking Essay's leash to her collar, but obviously I did that. I don't remember where Marshall was in any of this, but he was obviously there. My little Peanut. He's just a little guy, only thirty-five pounds to Essay's sixty-seven, and when we brought him home, we also had Wrigley, who weighed in at around seventy. 
So, next to his two big sisters, he was just a little peanut. And the nickname stuck. He's our Marshall Peanut.

I named Essay. We adopted her just two weeks after we lost my soul-mate dog, Annabelle, and I was so grief stricken I needed a name to mark that grief. "To essay is to attempt, to test, to make a run at something without knowing whether you will succeed," writes Phillip Lopate (xlii). l'd been teaching a course on the personal essay for a number of years at that point; it was my favorite course to teach, my favorite genre to both read and write, and I had recently read David Wroblewski's novel The Story of Edgar Sawtelle in which a dog named Essay makes an appearance. Until reading that book, I had never considered Essay a name, but once I saw someone else use it, I was sold.

She earned the nickname George not long after she came to us because she was so stinking curious. She had her nose in everything, so Curious George she became. Essay morphed to Essay-George, which sometimes just turns into George or Georgie. Lots of people think she's a boy because of this.

We are supposed to have control over our dogs, to be able to dictate their actions with a word or a command. We who want to count ourselves among the good dog owners are supposed to have spent hours and hours training them when they were young to come to us when called, to stay when we tell them to, to roll over for other people's pleasure. But Steve and I have never really done that. I think we just don't have the patience. This doesn't mean Essay and Marshall are bad dogs or that we don't have control over them. It might mean, to some people, that we are not good dog owners.

We are good dog companions. We give our dogs a warm and safe home, quality food, generous treats, plenty of toys. But more importantly, we give them so much love and attention. We walk them twice a day. We take them to dog parks. We play tug and fetch with them. We take them for rides, each dog on one side of the car, head sticking out the window. They sleep in bed with us, snuggled right up against our bodies. They cuddle up against us at night as we read or watch TV. They are a part of our family, and we talk to them and care for them better than we care for ourselves.

What is really at the heart of the fantasy of controlling our dogs? Are dogs not creatures with their own volition? When I was a kid growing up in a home in which I had incredibly little control over anything in my life, all I wanted was control. I couldn't wait until I grew up so I could eat Burger King for every meal if I wanted to. Abused by my older sister, I had no control over my own body. Even while I slept, I was the victim of harsh slurs, as my sister would walk through my room on her way to the bathroom and call me a "fat fuck" or a "shithead" or tell me I was "dead as soon as Ma left the house." To control what I could, I got good grades and became an avid reader. My librarian set aside new books for me, and I devoured them with Mindy the cat by my side. I couldn't control her either. When she was done sleeping by me, she'd up and leave and l'd be by myself. I controlled the things I had control over, which was basically my schoolwork. I was diligent and obedient and a quick study. I earned all As. I received affirmation at school and none at home. This did not help me emotionally. I was still a wreck inside, scared of my own family, unsafe at home. Always yearning to get out. Desperate to be alone.

Now, during the COVID-19 pandemic, Steve and I are home all the time and home is safe. Essay and Marshall are not accustomed to our being home so much, and Essay enforces her routines even more than normal. She's always been a creature of routine, making it very clear to us when $3: 30$ rolls around each day that it's time for her walk. We used to joke about it, and a year ago when she had to be kept overnight at the hospital after surgery on her knee, we laughed out loud when we realized she wasn't there telling us what to do. We didn't know what time to get up, what time to eat breakfast, what time to take a walk.

Now, as we try to figure out what made Essay go after the other dog in the park after l'd let her run off-leash, we come back to our being home all the time. Steve and I are both working from home, but I have much more flexibility than he does. He is at his computer most of the day, so I walk the dogs during the week. This means Essay is with me all day, every day. She was already attached to me, clingy even, and having me home with her all the time doesn't give her a chance to miss me. So perhaps, we figured, as we talked through the incident at the park, she was feeling more protective of me than usual and she understood Casey as a threat in some way.

When the woman, whose name, it turns out, is Barb, got up off the ground and brushed herself off, she noticed Casey's limp, started to cry, put her head in her hands, and told me she was going to need to get my information.

"Of course," I said. "Of course. I can text it to you if you give me your number."

She didn't have her phone with her. "Can I trust you to do that?"

"Yes. You can."

And then, "She's fourteen years old and she's hurt."

She then asked me to walk over to her yard with her. Turns out her house backed up to the park, so when she said she saw us out here every morning, she meant it. I walked slowly, lagging behind, texting her as I went. My whole body was shaking. I tried to keep my thoughts from racing, but my dog had just attacked a fourteen-year-old dog and what if she bit her and what if the dog died and is she going to sue us and Essay has never done anything like this before and what is wrong with Essay and oh my god, the dog is fourteen years old. 
When we got to her yard and Barb retrieved her cell phone, I apologized again and said, "I know these words are hollow, but Essay really has never done anything like this before. I would be angry, too, if I were you."

Hollow words. Empty words. I am a person who studies the effects of language, and in that moment all I could do was offer words anybody else in my position would offer. Words that meant nothing. Words that did nothing. Words I knew were hollow. So I said them again to try to solidify them.

"I know these words are hollow, but I truly am sorry. She won't be running here again. She's really never done anything like this before."

Can words touch us? During a time when we cannot touch each other, can words touch us in places where we hurt? Can we reach out with just the right words and have an impact when our hands or arms cannot? I want to believe they can.

"She's never done anything like this before," I told Barb about Essay. And now I think, we've never been through anything like this before, all of us required to stay home, to work from home if we can, to distance ourselves from each other. To refrain from touch. Touch is a primary form of communication. Violence is a kind of touch. Violence, of course, is a form of communication. It sends messages of pain and frustration and hatred. It sends the message "I am hurting."

As soon as I was done giving her my information, I turned around and began walking home. Once I was out of the park, I called Steve and began sobbing. I asked him to pick us up. I knew I could walk, but I didn't want to. I didn't want anybody to see me sobbing along the way. At home, sitting on the stairs so we could both pet Essay, I was still shaking, sobbing as I tried to tell Steve everything that had happened. And then I spent three hours staring at my phone waiting for an update from Barb, imagining worst-case scenarios.

"What if the dog has a heart attack from the suddenness of the attack? What if she dies? What if her leg is broken and they decide they don't want to put her through the pain of the recovery process and they put her down and it's all George's fault?"

"None of that is gonna happen," Steve assured me.

"The dog is fourteen."

"I know. She's gonna be okay."

"But is Essay okay? Why did she do this?"
"I don't know. She's gonna be okay."

We don't tell very many stories that enact empathy for the attacker and here I was, the owner of the attacker, desperately trying to find a way to live with the fact that my dog had attacked another dog for what seemed like no reason. I didn't know if I could have empathy for myself. I was the one who broke the rules and let her run off-leash. I needed to have empathy for Essay. I needed to know what was wrong with her.

I have lived my entire life with the mindset of the victim, and I have even made it part of my professional work to call out the abusers. I write about sibling abuse, calling on others to recognize it for what it is: the most common form of domestic violence and not just sibling rivalry. I write about misogyny in places you might not expect to find it, like the academy, where we're all allegedly progressive. I know so many people have stories of being victimized because so many people have shared their stories with me. What I didn't know was that people would also share their stories of their dogs behaving badly in order to make me feel better. I needed those stories so badly.

What I didn't know was that it hurts so badly to be on the other side of this dynamic.

I got onto the computer and researched aggression in older dogs-Essay is nine-and came up with all kinds of possibilities. She could be more aggressive because she has a painful tooth or because she's losing her vision or because she has some kind of internal pain or because she's developing dementia. We already had a vet appointment set up for a couple weeks out, but I wanted to talk to our vet before that. I needed to know that there was nothing wrong with our girl.

After lunch, I finally received a text from Barb telling me her vet-same veterinary hospital we go to-told her not to come in unless it was an emergency and to keep an eye on Casey. And she thanked me for checking on Casey. Deep sigh of relief. Casey wasn't going to die.

I've trusted in words for so long. They're my life's work. They're my lifeline. They show up in my dreams, formed into sentences and paragraphs. I try to capture them when I wake.

Once I even had a dream in which the everyday things I did were formatted into MLA format. As in: Robillard, Amy E. Walked to parking garage. Normal, IL. October 10, 2019.

In 2020, though, I sit in front of this same screen for so many hours a day, feeding it words and consuming the words it gives me. The words it gives me sometimes are harsh. I read the news and it tells me that we are all at risk of contracting this deadly virus at the same time that the president downplays it at the same time 
that tens of thousands of people are dying of it and that the early narrative we heard about young people being relatively safe from it is simply not true. I read the news and it tells me that Breonna Taylor has been killed while sleeping in her own home and none of the officers responsible for her murder have been arrested and I keep seeing the words over and over again and I add to them, too: Arrest the officers who murdered Breonna Taylor. I read the news and it tells me Ahmaud Arbery was lynched while out jogging and I want to turn off the computer. But I know I cannot.

To stave off the endless flow of words that come from this screen, I toggle over to Word and I feed different words into it, hoping to ward off the fear and loathing and anger the pandemic has brought out in me. I'm always asking students to think about what words do and now that I think about the give and take of the words on this same screen - the same screen-I wonder, too, about what words do. Do they stave off panic? Do they make me feel less alone? Do I write because I seek fellowship? Do I hope that by writing about Essay's attack I will somehow be absolved of it? That words will perform a kind of affective alchemy?

Later that afternoon, I was walking Essay and Marshall at a nearby trail when I received another text from Barb telling me she was going to take Casey to the vet after all. Casey was still in pain and couldn't walk and she seemed to be getting worse. I told her to have them call me so we could pay the bill.

About an hour later, our vet's receptionist, Jen, called to get payment information and told me Casey was going to be okay. When she expressed her disbelief that Essay had done this, I nearly wept with gratitude. I needed someone neutral to be in disbelief about Essay, too. And then she told me a long and involved story about the time she was dogsitting a friend's dog and her own dog attacked the visiting dog for what seemed like no reason.

"Sometimes this just happens," she told me. "It's not just Essay."

And I told her I was worried something was wrong with Essay, so we moved up our appointment a week. Before we hung up, she assured me that these things sometimes happen for no reason and that, most likely, there was nothing wrong with Essay. It didn't mean she's a bad dog.

When she said those words, I nearly doubled over. I didn't know how badly I needed to hear them. I didn't know until that moment how much my own identity was wrapped up with Essay's behavior that morning, how my understanding of myself as a good dog owner was contingent upon Essay doing all the right things, on her being a good girl at all times. And Jen reminded me, too, that Essay is probably a little off because Steve and I are home all the time. And I felt so much better. I needed those words so badly.
The next day my friend Katherine reminded me of the time her own dog bit the electrician and she was worried for days he was going to sue her. I had forgotten all about it. The only other friend I told about the attack told me how much she loved Essay and that Essay would always be her girl.

What does it mean to be a good person during a pandemic? We're told it means staying home and maintaining social distancing and wearing masks when out in public. We're told it means not going to the store for unnecessary items no matter how badly we need that bag of soil for our garden.

There is a kind of violence enacted in leaving the house for frivolous reasons because we take our own and others' lives into our hands. It's hard to wrap our heads around this because the coronavirus is invisible, it is carried by asymptomatic people, and we could all be guilty of inflicting harm.

We communicate now with our bodies, with what we do with our bodies. Where we put them. What we put on them. Whether we take them out in public. The protesters who want the states to reopen prematurely enact a violence with their bodies as they put them out there in public and then bring them back home to their families. As they then interact with all of us.

Essay communicated with her body when she attacked Casey. It's the only way she knows.

At Essay's vet appointment a week later, Dr. Burks examined Essay and found nothing wrong. She told me she was hearing so many stories of animals behaving badly because their people were home all the time. Cats urinating everywhere but the litter box, dogs doing things they would never otherwise do.

"Essay is not alone," she said.

Those words again. I needed those words.

We've all heard the saying "hurt people hurt people." We know that, on some level, people who abuse others do so to some degree because they are in pain. I used to take comfort in this knowledge, my logic being that if they're going to inflict pain on others then they deserve the pain they're in. I see it a little differently now. I would never ask Barb or her husband to try to understand what I went through after Essay attacked Casey; I would never ask a victim to empathize with an attacker. Never. But I needed desperately that day to be understood, to feel like I wasn't alone, and I needed Essay to continue to be loved. Without feeling those things, I'm not sure how I could have carried on.

Can words touch people? Yes. Yes, they absolutely can. 
What facilitated those feelings was other people's words. Words carried to me through the telephone from friends who understood on some level that I needed to hear them. They weren't words I read on the page or on the screen, but putting them here on this screen will, I hope, facilitate similar feelings in others. This is how this works. We share words, we tell stories, we assess a situation and we decide which words fit best. We gauge how a person is feeling, how that person wants to feel, what we can do to facilitate those feelings, and we choose our words carefully. And we share them. We sometimes reach for words that have been used over and over again to the point that they're worn out from overuse and we pad them to show we really mean them. Life is a series of incidents we walk through for the first time, following others who have experienced similar incidents for the first time and who came up with words to describe them. And we add to those words. We write.

$* * *$

On our morning walks, we still go to the park, but Essay never runs off-leash. We've run into Casey and her dad walking a few times, and always we turn around and take a different route. I probably look like a coward. But what I want most is for him not to have to see us. I want us to not exist for him. I see sweet little Casey-she's probably 45 pounds, in between Marshall's and Essay's sizes-trotting along and my eyes begin to water because she is a good girl and she did nothing to deserve what Essay did. I want to pet her and tell her I'm sorry. I want her to be happy. She looks happy.

\section{Works Cited}

Lopate, Phillip. "Introduction." The Art of the Personal Essay. New York: Anchor, 1995.

Wroblewski, D. (2009). The Story of Edgar Sawtelle. Anchor Canada.

\section{Acknowlegment}

The author would like to thank Sarah Hochstetler for her fabulous early feedback on this piece and for her friendship. And thanks, too, to Steve Field, for living this with me. 